\title{
Coordination Chemistry of a Molecular Pentafoil Knot
}

\author{
Liang Zhang, ${ }^{\dagger, \ddagger(i) ~ A l e x a n d e r ~ J . ~ S t e p h e n s, ~}{ }^{\ddagger}$ Jean-François Lemonnier, Lucian Pirvu, \\ Iñigo J. Vitorica-Yrezabal, ${ }^{\ddagger}$ Christopher J. Robinson, ${ }^{\S(0)}$ and David A. Leigh ${ }^{*},+\neq 0$ \\ ${ }^{\dagger}$ School of Chemistry and Molecular Engineering, East China Normal University, Shanghai 200062, China \\ ${ }^{\ddagger}$ School of Chemistry, University of Manchester, Manchester M13 9PL, United Kingdom \\ ${ }^{\S}$ SYNBIOCHEM, Manchester Institute of Biotechnology, University of Manchester, Manchester M1 7DN, United Kingdom
}

\section{Supporting Information}

ABSTRACT: The binding of $\mathrm{Zn}(\mathrm{II})$ cations to a pentafoil $\left(5_{1}\right)$ knotted ligand allows the synthesis of otherwise inaccessible metalated molecular pentafoil knots via transmetalation, affording the corresponding "first-sphere" coordination $\mathrm{Co}(\mathrm{II}), \mathrm{Ni}(\mathrm{II})$, and $\mathrm{Cu}(\mathrm{II})$ pentanuclear knots in good yields $(\geq 85 \%)$. Each of the knot complexes was characterized by mass spectrometry, the diamagnetic (zinc) knot complex was characterized by ${ }^{1} \mathrm{H}$ and ${ }^{13} \mathrm{C}$ NMR spectroscopy, and the zinc, cobalt, and nickel pentafoil knots afforded single crystals whose structures were determined by X-ray crystallography. Lehn-type circular helicates generally only form with tris-bipy ligand strands and $\mathrm{Fe}$ (II) (and, in some cases, $\mathrm{Ni}$ (II) and $\mathrm{Zn}$ (II)) salts, so such architectures become accessible for other metal cations only through the use of knotted ligands. The different metalated knots all exhibit "second-sphere" coordination of a single chloride ion within the central cavity of the knot through $\mathrm{CH}^{\circ} \cdot \mathrm{Cl}^{-}$hydrogen bonding and electrostatic interactions. The chloride binding affinities were determined in $\mathrm{MeCN}$ by isothermal titration calorimetry, and the strength of binding was shown to vary over 3 orders of magnitude for the different metal-ion-knotted-ligand second-sphere coordination complexes.

\section{INTRODUCTION}

Molecular knots and entanglements occur in DNA, ${ }^{1}$ some proteins, ${ }^{2}$ and form spontaneously in polymer chains ${ }^{3}$ of sufficient length and flexibility. ${ }^{4}$ Synthetic routes to several small-molecule knots have been developed, ${ }^{5,6}$ or serendipitously discovered, ${ }^{7}$ and physical and chemical consequences of knotting have been demonstrated, ${ }^{4}$ including anion binding, ${ }^{7 \mathrm{~h}, 8}$ asymmetric, ${ }^{9}$ and allosteric regulation ${ }^{10}$ of catalysis, and the securing of a threaded structure by the increase in steric bulk that accompanies tying a knot in a molecular strand. ${ }^{11}$ However, despite metal template synthesis being a common route to molecular knots, ${ }^{4 a, c, f, h, 5 a, c-k, 7 d, 8}$ effects on metal-ion coordination induced by knotting of the ligand strand have rarely ${ }^{10,12}$ been described.

We recently reported that a pentafoil $\left(5_{1}\right)$ knot could be prepared by ring-closing olefin metathesis (RCM) of a pentameric circular $\mathrm{Fe}(\mathrm{II})_{5}$-helicate. ${ }^{10}$ The framework of this $5_{1}$ knot contains only kinetically robust covalent bonds, and so, unlike previous examples, ${ }^{5 e, f}$ the metal ions can be removed from a molecular pentafoil knot without destroying the knot topology. Direct remetalation of the knotted ligand proved only possible with $\mathrm{Zn}(\mathrm{II})$ cations, presumably because the coordination dynamics of other metal(II) cations is too slow to allow "mistakes" regarding which bipyridine moieties coordinate to which metal ion to be corrected. However, complexation of the five $\mathrm{Zn}$ (II) cations holds the knotted ligand in the conformation necessary to bind to five metal ions. We reasoned that this might enable sequential substitution of other metal(II) cations ${ }^{12}$ for $\mathrm{Zn}$ (II) without permitting the knotted ligand to adopt conformations that can bind to incoming metal ions through "wrong" combinations of bipyridine units. ${ }^{13}$ Here, we show that this enables the efficient synthesis of the otherwise inaccessible $\mathrm{Co}(\mathrm{II}), \mathrm{Ni}(\mathrm{II})$, and $\mathrm{Cu}$ (II) metalated knots, enabling the exploration of the coordination chemistry of the knotted ligand. The unknotted ligand monomer only forms circular helicates with $\mathrm{Fe}$ (II) and $\mathrm{Zn}(\mathrm{II}){ }^{10}$ and so the transmetalation strategy, and resulting breadth of coordination chemistry, is only achievable with a knotted ligand.

\section{RESULTS AND DISCUSSION}

Direct Metalation of Knotted Ligand 1. The coordination chemistry of pentafoil knot $\mathbf{1}$ was investigated by first probing the rate of metalation of $\mathbf{1}$ with different zinc(II) salts (Scheme 1, steps a,b). The rate and efficiency of introduction of the zinc(II) ions proved to be highly dependent on the salt used (Table 1). Treatment of 1 with $\mathrm{Zn}\left(\mathrm{BF}_{4}\right)_{2}$ in $\mathrm{MeOH} /$ $\mathrm{CH}_{2} \mathrm{Cl}_{2}$ (most conveniently followed using deuterated solvents) generated $\left[\mathrm{Zn}_{5} \mathbf{1} \cdot \mathrm{Cl}\right]\left(\mathrm{BF}_{4}\right)_{9}$ in $98 \%$ yield after $2 \mathrm{~h}$ at $40{ }^{\circ} \mathrm{C}$ followed by work-up with 1 equiv of $\mathrm{Bu}_{4} \mathrm{NCl}$ (Table 1 , entry 1). Introducing the metal ions with $\mathrm{Zn}\left(\mathrm{CF}_{3} \mathrm{SO}_{3}\right)_{2}$ proved more sluggish, resulting in a $44 \%$ yield of $\left[\mathrm{Zn}_{5} \mathbf{1}\right.$. $\mathrm{Cl}]\left(\mathrm{CF}_{3} \mathrm{SO}_{3}\right)_{9}$ after $16 \mathrm{~h}$ and work-up (Table 1 , entry 2 ). However, treatment of 1 with $\mathrm{ZnCl}_{2}$ afforded $\left[\mathrm{Zn}_{5} \mathbf{1} \cdot \mathrm{Cl}\right]\left(\mathrm{BF}_{4}\right)_{9}$ quantitatively in less than $5 \mathrm{~min}$ at room temperature, followed

Received: November 22, 2018

Published: February 11, 2019 
Scheme 1. Metallation of Knotted Ligand 1 To Generate the Corresponding M(II) $)_{5}-1$ Knot Complexes ${ }^{a}$

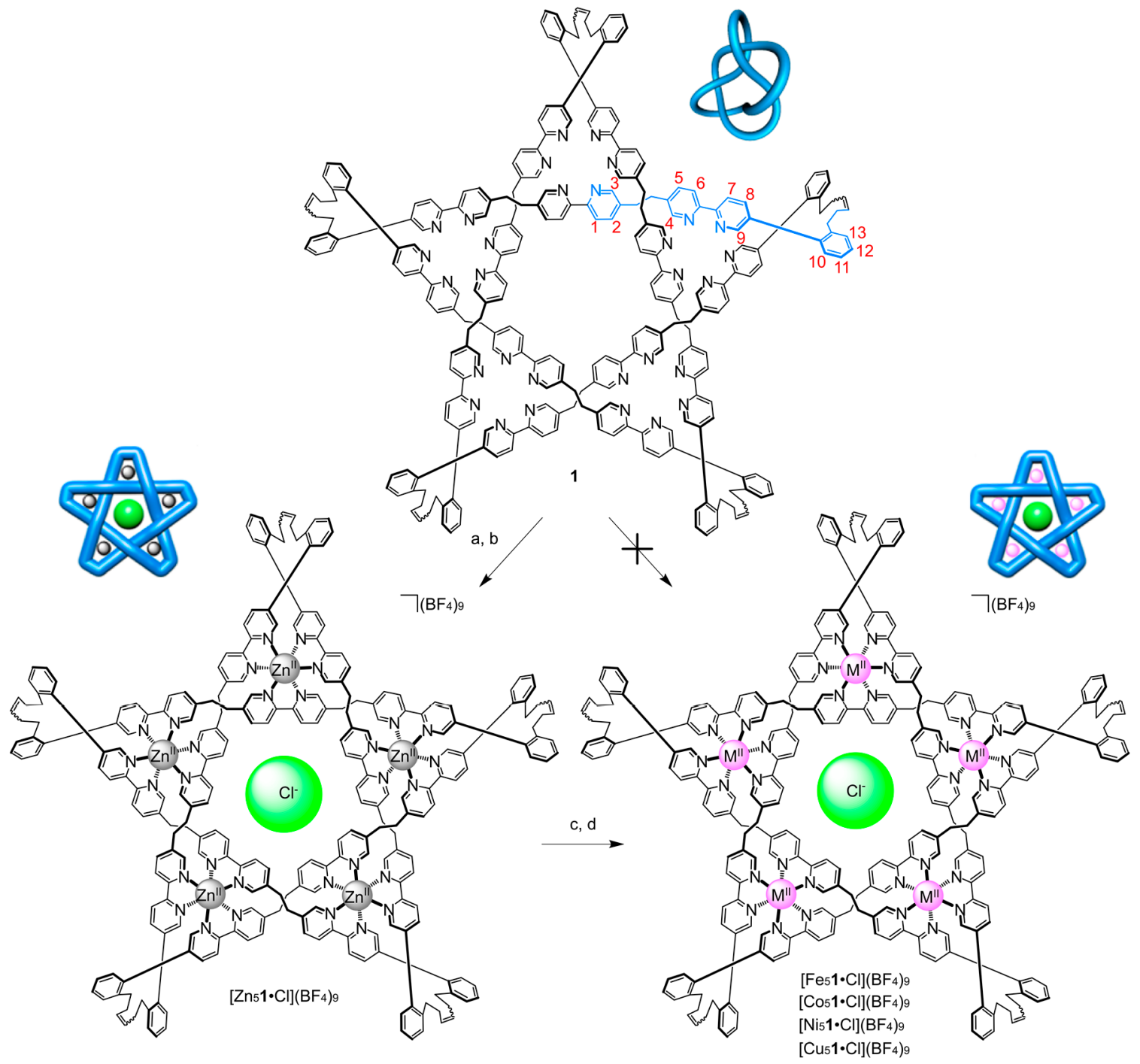

${ }^{a}$ Reagents and conditions: (a) $\mathrm{ZnCl}_{2}$, dichloromethane/methanol (1:1), room temperature, $<5 \mathrm{~min}$; (b) saturated $\mathrm{NH}_{4} \mathrm{BF}_{4}$ (quantitative yield over two steps); (c) $\mathrm{M}\left(\mathrm{BF}_{4}\right)_{2}\left(\mathrm{M}=\mathrm{Fe}(\mathrm{II}), \mathrm{Co}(\mathrm{II}), \mathrm{Ni}(\mathrm{II}), \mathrm{Cu}(\mathrm{II})\right.$ ), acetonitrile/methanol (10:1), $80{ }^{\circ} \mathrm{C}, 2-4$ days; (d) $\mathrm{NBu}_{4} \mathrm{Cl} 1$ equiv per metalated pentafoil knot $\left(94 \%\left[\mathrm{Fe}_{5} 1 \cdot \mathrm{Cl}\right]\left(\mathrm{BF}_{4}\right)_{9}, 92 \%\left[\mathrm{Co}_{5} 1 \cdot \mathrm{Cl}\right]\left(\mathrm{BF}_{4}\right)_{9}, 88 \%\left[\mathrm{Ni}_{5} \mathbf{1} \cdot \mathrm{Cl}\right]\left(\mathrm{BF}_{4}\right)_{9}, 85 \%\left[\mathrm{Cu}_{5} \mathbf{1} \cdot \mathrm{Cl}\right]\left(\mathrm{BF}_{4}\right)_{9}\right)$.

Table 1. Synthesis of $\left[\mathrm{Zn}_{5} 1 \cdot \mathrm{Cl}\right]^{9+}$ from 1 with Various Zinc Salts

\begin{tabular}{cllccc}
\hline entry & \multicolumn{1}{c}{$\mathrm{Zn}$ salts } & \multicolumn{1}{c}{ solvent } & $\begin{array}{c}\text { temp } \\
\left({ }^{\circ} \mathrm{C}\right)\end{array}$ & time $(\mathrm{h})$ & $\begin{array}{c}\text { yield } \\
(\%)\end{array}$ \\
\hline 1 & $\mathrm{Zn}\left(\mathrm{BF}_{4}\right)_{2}$ & $\mathrm{MeOH} / \mathrm{CH}_{2} \mathrm{Cl}_{2}$ & 40 & 2 & $98^{a}$ \\
2 & $\mathrm{Zn}\left(\mathrm{CF}_{3} \mathrm{SO}_{3}\right)_{2}$ & $\mathrm{MeOH} / \mathrm{CH}_{2} \mathrm{Cl}_{2}$ & 40 & 16 & $44^{a}$ \\
3 & $\mathrm{ZnCl}_{2}$ & $\mathrm{MeOH} / \mathrm{CH}_{2} \mathrm{Cl}_{2}$ & $\mathrm{rt}$ & $<5$ min & quant. $^{b}$
\end{tabular}

${ }^{a}$ After workup with 1 equiv of $\mathrm{Bu}_{4} \mathrm{NCl} .{ }^{b}$ After anion exchange with $\mathrm{KBF}_{4}$.

by exchange of the nine noncavity bound $\mathrm{Cl}^{-}$anions for $\mathrm{BF}_{4}^{-}$ for solubility reasons (Table 1 , entry 3 ).

The X-ray crystal structure of $\left[\mathrm{Zn}_{5} \mathbf{1} \cdot \mathrm{Cl}\right]\left(\mathrm{PF}_{6}\right)_{9}$ features a chloride anion tightly bound in the central cavity as a consequence of electrostatic interactions and $10 \mathrm{CH} \cdots \mathrm{Cl}^{-}$ hydrogen bonds (Figure $2 \mathrm{c}$ and f). ${ }^{10}$ Given the very different rates of metalation with the different zinc salts, it seems likely that halide binding in the central cavity plays a significant role in facilitating the metalation of the knotted ligand, encouraging rapid rearrangement of wrongly coordinated bipyridine residues. In the ${ }^{1} \mathrm{H}$ NMR spectrum of the titration of $\mathrm{ZnCl}_{2}$ into knot 1 , free ligand and $\left[\mathrm{Zn}_{5} \mathbf{1} \cdot \mathrm{Cl}\right]^{9+}$ signals dominate. Asymmetric species, that is, partially metalated pentafoil knots $\left[\mathrm{Zn}_{1-4} \mathbf{1} \cdot \mathrm{Cl}\right]^{1-7+}$, are only present in very minor amounts (Figure S13). Coordination of the first zinc cations to the knotted ligand appears to preorganize the remaining empty coordination pockets, expediting the subsequent coordination events.

In contrast to the complexation of the knotted ligand with $\mathrm{Zn}(\mathrm{II})$, direct metalation of $\mathbf{1}$ with some other first row transition metal salts (Fe(II), $\mathrm{Co}(\mathrm{II}), \mathrm{Ni}(\mathrm{II})$, or $\mathrm{Cu}(\mathrm{II})$ ) failed to generate isolable quantities of fully metalated knots, even over extended reaction times (up to $60 \mathrm{~h}$ ) at elevated temperatures (up to $80{ }^{\circ} \mathrm{C}$ ). ${ }^{14}$ Rather than start from metalfree ligand $\mathbf{1}$, we reasoned that as the $\mathrm{Zn}(\mathrm{II})$ cations in $\left[\mathrm{Zn}_{5} \mathbf{1}\right.$. $\mathrm{Cl}]\left(\mathrm{BF}_{4}\right)_{9}$ organize the binding sites of $\mathbf{1}$ in the correct arrangement, the labile $\mathrm{Zn}(\mathrm{II})$ ions of that complex might be exchanged for a less labile metal (introduced in large excess) in a stepwise process. Such stepwise transmetalation could allow the knotted ligand to retain the relative positions of its 
Table 2. ESI-MS Characterization of $\left[\mathrm{Zn}_{5} 1\right]\left(\mathrm{BF}_{4}\right)_{10}$ Treated with 10 equiv of $\mathrm{Fe}\left(\mathrm{BF}_{4}\right)_{2}$

\begin{tabular}{|c|c|c|c|c|c|c|c|c|}
\hline \multirow[b]{2}{*}{ pentafoil knot intermediates } & \multicolumn{2}{|c|}{$4+$ charged species } & \multicolumn{2}{|c|}{$5+$ charged species } & \multicolumn{2}{|c|}{$6+$ charged species } & \multicolumn{2}{|c|}{$7+$ charged species } \\
\hline & calcd & obsd & calcd & obsd & calcd & obsd & calcd & obsd \\
\hline$\left\{\left[\mathrm{Zn}_{4} \mathrm{Fe}_{1} \mathbf{1} \cdot \mathrm{Cl}\right]\left(\mathrm{BF}_{4}\right)_{9}-n \mathrm{BF}_{4}\right\}^{n+}$ & 1137.77 & & 892.85 & 892.50 & 729.57 & 729.50 & 612.95 & 613.00 \\
\hline$\left\{\left[\mathrm{Zn}_{3} \mathrm{Fe}_{2} \mathbf{1} \cdot \mathrm{Cl}\right]\left(\mathrm{BF}_{4}\right)_{9}-n \mathrm{BF}_{4}\right\}^{n+}$ & 1135.38 & 1136.08 & 890.94 & 890.92 & 727.98 & 728.00 & 611.59 & 610.92 \\
\hline$\left\{\left[\mathrm{Zn}_{2} \mathrm{Fe}_{3} \mathbf{1} \cdot \mathrm{Cl}\right]\left(\mathrm{BF}_{4}\right)_{9}-n \mathrm{BF}_{4}\right\}^{n+}$ & 1133.00 & & 889.04 & 888.80 & 726.40 & 726.61 & 610.22 & 610.71 \\
\hline$\left\{\left[\mathrm{Zn}_{1} \mathrm{Fe}_{4} \mathbf{1} \cdot \mathrm{Cl}\right]\left(\mathrm{BF}_{4}\right)_{9}-n \mathrm{BF}_{4}\right\}^{n+}$ & 1130.62 & 1130.67 & 887.13 & 887.08 & 724.81 & 724.83 & 608.86 & 608.83 \\
\hline
\end{tabular}

bipyridine chelating groups as the metals are successively exchanged, and hence reduce the degree of ligand strand rearrangement required.

Transmetalation of $\left[\mathrm{Zn}_{5} 1 \cdot \mathrm{Cl}\right]\left(\mathrm{BF}_{4}\right)_{9}$. The $\mathrm{Zn}_{5}$-pentafoil knot complex $\left[\mathrm{Zn}_{5} \mathbf{1} \cdot \mathrm{Cl}\right]\left(\mathrm{BF}_{4}\right)_{9}$ was treated with a 20 -fold excess of $\mathrm{Fe}\left(\mathrm{BF}_{4}\right)_{2}$ in $\mathrm{CH}_{3} \mathrm{CN}: \mathrm{CH}_{3} \mathrm{OH}$ (1:0.1), and heated to $80^{\circ} \mathrm{C}$ (Scheme 1, steps c,d). After 24 h, electrospray ionization mass spectrometry (ESI-MS) indicated almost complete conversion to a mixture of $\left[\mathrm{Fe}_{5} \mathbf{1} \cdot \mathrm{Cl}\right]\left(\mathrm{BF}_{4}\right)_{9}$ and $\left[\mathrm{Fe}_{5} \mathbf{1}\right]\left(\mathrm{BF}_{4}\right)_{10}$, with a small quantity of $\left[\mathrm{ZnFe}_{4} \mathbf{1} \cdot \mathrm{Cl}\right]\left(\mathrm{BF}_{4}\right)_{9}$ and $\left[\mathrm{ZnFe}_{4} \mathbf{1}\right]$ $\left(\mathrm{BF}_{4}\right)_{10}$ also present. To ensure full exchange of $\mathrm{Zn}(\mathrm{II})$ for $\mathrm{Fe}(\mathrm{II})$ in the knot, a further 20 -fold excess of $\mathrm{Fe}\left(\mathrm{BF}_{4}\right)_{2}$ was added, and heating continued for another $24 \mathrm{~h}$. After this time, the addition of 1 equiv of $\mathrm{NBu}_{4} \mathrm{Cl}$ with respect to $\left[\mathrm{Fe}_{5} 1\right]^{10+}$ (to avoid having a mixture of anions in the knot coordination complex) afforded $\left[\mathrm{Fe}_{5} \mathbf{1} \cdot \mathrm{Cl}\right]\left(\mathrm{BF}_{4}\right)_{9}$ as a red-purple solid. Highresolution (HR) ESI-MS (Figure S5) and ${ }^{1} \mathrm{H}$ NMR spectroscopy (Figure S11) confirmed the product composition.

${ }^{1} \mathrm{H}$ NMR (Figure S14) and ESI-MS (Table 2 and Figures S15-18) monitoring of the transmetalation process were consistent with the stepwise replacement of the $\mathrm{Zn}$ (II) cations in the knot. ${ }^{1} \mathrm{H}$ NMR shows the signals corresponding to $\left[\mathrm{Zn}_{5} \mathbf{1} \cdot \mathrm{Cl}\right]\left(\mathrm{BF}_{4}\right)_{9}$ broadening after addition of $\mathrm{Fe}\left(\mathrm{BF}_{4}\right)_{2}\left(\mathrm{H}_{2} \mathrm{O}\right)_{6}$ and their intensity decreasing. Concomitantly, signals corresponding to $\left[\mathrm{Fe}_{5} \mathbf{1} \cdot \mathrm{Cl}\right]\left(\mathrm{BF}_{4}\right)_{9}$ emerge.

Upon addition of 10 equiv of $\mathrm{Fe}\left(\mathrm{BF}_{4}\right)_{2}\left(\mathrm{H}_{2} \mathrm{O}\right)_{6}$ to an acetonitrile solution of $\left[\mathrm{Zn}_{5} \mathbf{1} \cdot \mathrm{Cl}\right]\left(\mathrm{BF}_{4}\right)_{9}$, aliquots were analyzed every hour by ESI-MS (Table 2, Figures S15-18), and the evolution of hetero penta-metalated knots $\left\{\left[\mathrm{Zn}_{4} \mathrm{Fe} \mathbf{1}\right.\right.$. $\left.\mathrm{Cl}]\left(\mathrm{BF}_{4}\right)_{9-n}\right\}^{n+}, \quad\left\{\left[\mathrm{Zn}_{3} \mathrm{Fe}_{2} \mathbf{1} \cdot \mathrm{Cl}\right]\left(\mathrm{BF}_{4}\right)_{9-n}\right\}^{n+}, \quad\left\{\left[\mathrm{Zn}_{2} \mathrm{Fe}_{3} \mathbf{1} \cdot \mathrm{Cl}\right]-\right.$ $\left.\left(\mathrm{BF}_{4}\right)_{9-n}\right\}^{n+}$, and $\left\{\left[\mathrm{ZnFe}_{4} \mathbf{1} \cdot \mathrm{Cl}\right]\left(\mathrm{BF}_{4}\right)_{9-n}\right\}^{n+}$ followed. No species featuring four or less metal ions were detected. The results are consistent with a stepwise transmetalation process where one zinc cation is substituted by an iron center at a time without the need for major reorganization of the knotted ligand. $^{15}$

In analogous fashion, knots $\left[\mathrm{Co}_{5} \mathbf{1} \cdot \mathrm{Cl}\right]\left(\mathrm{BF}_{4}\right)_{9},\left[\mathrm{Ni}_{5} \mathbf{1} \cdot \mathrm{Cl}\right]$ $\left(\mathrm{BF}_{4}\right)_{9}$, and $\left[\mathrm{Cu}_{5} \mathbf{1} \cdot \mathrm{Cl}\right]\left(\mathrm{BF}_{4}\right)_{9}$ were formed by the transmetalation of $\left[\mathrm{Zn}_{5} \mathbf{1} \cdot \mathrm{Cl}\right]\left(\mathrm{BF}_{4}\right)_{9}$ with the respective metal tetrafluoroborate salts, followed by work-up with 1 equiv of $\mathrm{Bu}_{4} \mathrm{NCl}$ (Scheme 1, steps c,d). Longer reaction times were required for the complete exchange with $\mathrm{Zn}$ (II) in the order: $\mathrm{Co}\left(\mathrm{BF}_{4}\right)_{2}(2$ days $)<\mathrm{Ni}\left(\mathrm{BF}_{4}\right)_{2} \approx \mathrm{Cu}\left(\mathrm{BF}_{4}\right)_{2}$ (4 days). Reaction progress was monitored by mass spectrometry until no heterometallic species were detected. The paramagnetic nature of $\mathrm{Co}(\mathrm{II}), \mathrm{Ni}(\mathrm{II})$, and $\mathrm{Cu}(\mathrm{II})$ precluded obtaining structural information for those pentametallic knots by NMR spectroscopy, but ESI-MS confirmed the isolation of homometallic coordination complexes (e.g., Figure 1 and Figures S4-10). The mass spectrometry results show selective association of each metalated knot with a single chloride anion. The UV-vis spectra of the $\mathrm{Fe}(\mathrm{II}), \mathrm{Zn}$ (II) $\mathrm{Co}(\mathrm{II}), \mathrm{Ni}(\mathrm{II})$, and $\mathrm{Cu}(\mathrm{II})$ knot complexes are similar to those of the known $\mathrm{Fe}(\mathrm{II}), \mathrm{Zn}(\mathrm{II})$,

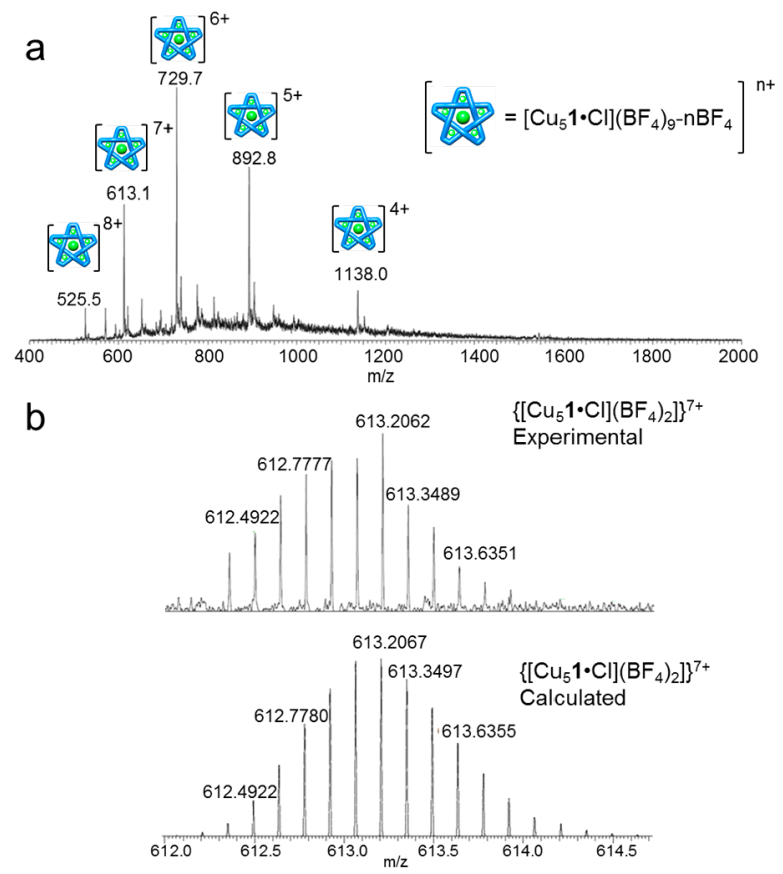

Figure 1. (a) Low-resolution ESI-MS of pentafoil knot $\left[\mathrm{Cu}_{5} \mathbf{1}\right.$. $\mathrm{Cl}]\left(\mathrm{BF}_{4}\right)_{9}$. Calculated peaks $(\mathrm{m} / z): 1138.1\left[\mathrm{M}-4 \mathrm{BF}_{4}\right]^{4+} ; 893.1[\mathrm{M}$ $\left.-5 \mathrm{BF}_{4}\right]^{5+} ; 729.7\left[\mathrm{M}-6 \mathrm{BF}_{4}\right]^{6+} ; 613.2\left[\mathrm{M}-7 \mathrm{BF}_{4}\right]^{7+} ; 525.4[\mathrm{M}-$ $\left.8 \mathrm{BF}_{4}\right]^{8+}$. The minor peaks observed at $\mathrm{m} / z=532.1,620.3,738.4$, 903.2, and 1150.5 are corresponding to the $\left\{\left[\mathrm{Cu}_{5} \mathbf{1}\right]\left(\mathrm{BF}_{4}\right)_{\left.10^{-}-n \mathrm{BF}_{4}\right\}^{n+}}\right.$ species and mainly originated from exchanges of cavity chloride and tetrafluoroborate anions. (b) High-resolution ESI-MS of the [M $\left.7 \mathrm{BF}_{4}\right]^{7+}$ peak of $\left[\mathrm{Cu}_{5} \mathbf{1} \cdot \mathrm{Cl}\right]\left(\mathrm{BF}_{4}\right)_{9}$. Experimental spectrum (top) and calculated spectrum (bottom).

$\mathrm{Co}(\mathrm{II}), \mathrm{Ni}(\mathrm{II})$, and $\mathrm{Cu}(\mathrm{II})\left[\mathrm{M}\left(5,5^{\prime} \text {-dimethyl-2,2' -bipy }\right)_{3}\right]^{2+}$ complexes (Figures S25-S29).

X-ray Crystal Structures of Metalated Pentafoil Knots. Slow diffusion of diisopropylether or toluene into a concentrated acetonitrile solution of $\left[\mathrm{M}_{5} \mathbf{1} \cdot \mathrm{Cl}\right]\left(\mathrm{BF}_{4}\right)_{9}(\mathrm{M}=$ $\mathrm{Co}, \mathrm{Zn}$, or $\mathrm{Ni}$ ) afforded crystals of suitable quality for X-ray diffraction on beamline I19 at the Diamond light Source (UK). The three crystal structures are broadly similar (Figure 2) but with slightly different conformations of the knotted ligand to accommodate the different sized metal ions. In each structure, the 190-atom-long pentafoil knotted ligand wraps around each of the metal ions in a closed loop double helicate. Five of the 15 bipyridine groups form an inner cavity lined with 10 electron-poor hydrogen atoms that form an array of hydrogen bonds with the chloride anion located inside the cavity $(\mathrm{CH} \cdots$ $\mathrm{Cl}^{-}$distances given in Table 3). The cavity diameters vary depending on the metal cation: $\mathrm{Fe}(\mathrm{II}), \mathrm{Zn}(\mathrm{II})$, and $\mathrm{Ni}(\mathrm{II})$, 3.3(1) Å cavities; Co(II), 3.5(1) Å. The cobalt pentafoil knot dimensions are also more distorted from that of a regular pentagon than the other metalated knots: standard deviations of the metal-metal distances $0.6 \AA$ for the cobalt knot as 
a

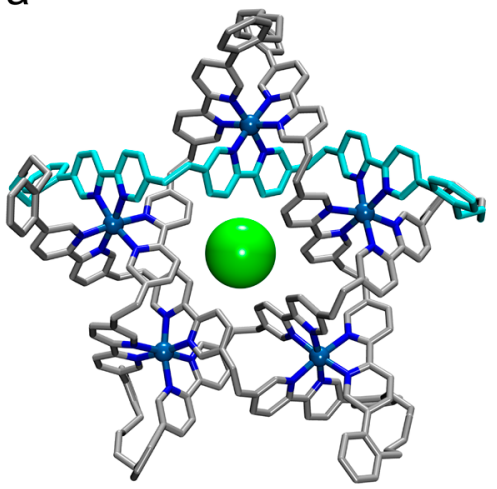

d

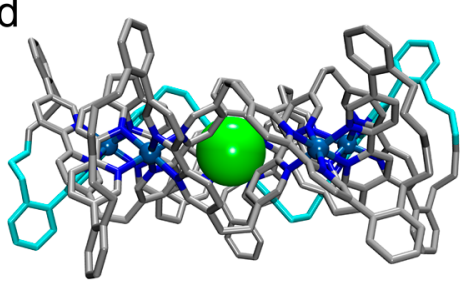

b

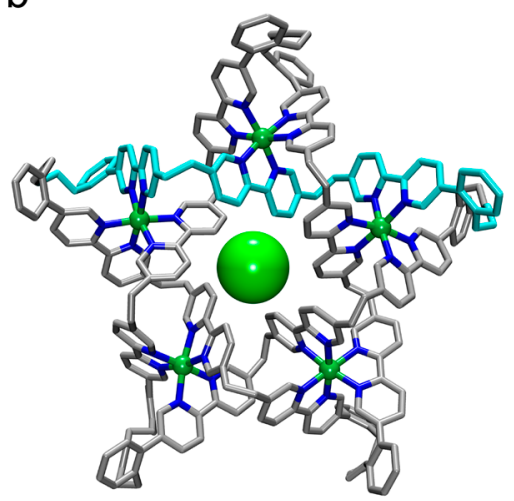

e

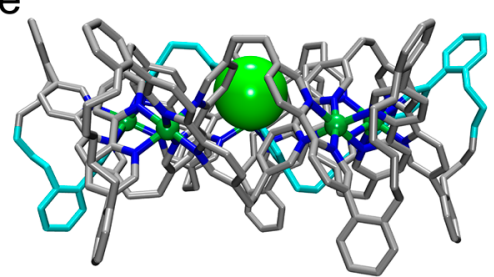

C

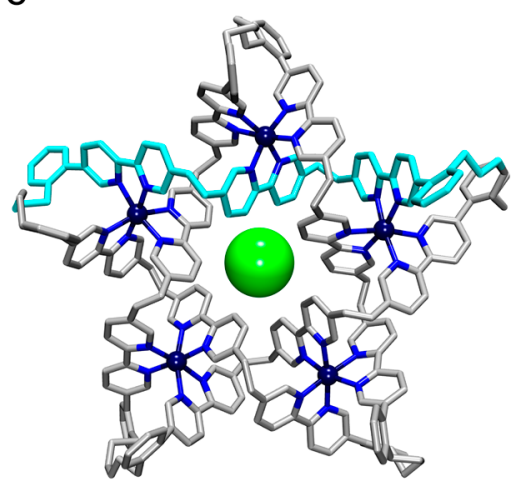

f

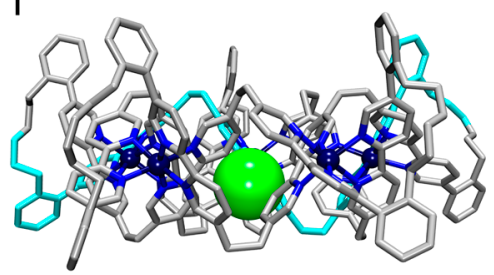

Figure 2. X-ray crystal structures of $\left[\mathrm{Co}_{5} \mathbf{1} \cdot \mathrm{Cl}\right]\left(\mathrm{BF}_{4}\right)_{9},\left[\mathrm{Ni}_{5} \mathbf{1} \cdot \mathrm{Cl}\right]\left(\mathrm{BF}_{4}\right)_{9}$, and $\left[\mathrm{Zn}_{5} \mathbf{1} \cdot \mathrm{Cl}\right]\left(\mathrm{BF}_{4}\right)_{9} \cdot(\mathrm{a}-\mathrm{c})$ Views from above the central cavity, $(\mathrm{d}-\mathrm{f})$ views in the plane of the metalated knots: $(\mathrm{a}, \mathrm{d})\left[\mathrm{Co}_{5} \mathbf{1} \cdot \mathrm{Cl}\right]\left(\mathrm{BF}_{4}\right)_{9},(\mathrm{~b}, \mathrm{e})\left[\mathrm{Ni}_{5} \mathbf{1} \cdot \mathrm{Cl}\right]\left(\mathrm{BF}_{4}\right)_{9}$, and $(\mathrm{c}, \mathrm{f})\left[\mathrm{Zn}_{5} \mathbf{1} \cdot \mathrm{Cl}\right](\mathrm{BF})_{4}$. In each structure, carbon atoms are light gray (except for one building block strand in which the $\mathrm{C}$ atoms are colored turquoise); N, blue; Co, teal; $\mathrm{Ni}$, dark green; $\mathrm{Zn}$, deep blue; the central chloride ion is shown at $99 \%$ van der Waals radius as a green sphere. Other anions, residual solvent molecules, and hydrogen atoms are omitted for clarity.

Table 3. X-ray Crystal Structure Parameters of Pentametalated Knots ${ }^{a}$

$\begin{array}{ccccccc}\text { cation } & \mathrm{M}-\mathrm{N} \text { distance }(\AA) & \mathrm{M}-\mathrm{M} \text { distance }(\AA) & \mathrm{M}-\mathrm{M}-\mathrm{M} \text { angles }(\mathrm{deg}) & \text { cavity size }(\AA) & \mathrm{CH} \cdots \mathrm{Cl} \text { distance }(\AA) \\ \mathrm{Fe}^{\mathrm{II}} & 2.0(1) & 8.3(1) & 108.8,108.3,108.8,107.9,106.7 & 3.3(1) & 2.8(1) \\ \mathrm{Co}^{\mathrm{II}} & 2.1(1) & 8.6(6) & 105.3,105.5,106.5,110.2,110.5 & 3.5(1) & 2.8(1) \\ \mathrm{Ni}^{\mathrm{II}} & 2.1(1) & 8.4(1) & 106.3,107.0,107.1,109.4,110.2 & 3.4(1) & 2.8(1) \\ \mathrm{Zn}^{\mathrm{II}} & 2.2(1) & 8.5(2) & 106.7,107.1,107.1,107.8,111.3 & 3.3(1) & 2.7(1)\end{array}$

${ }^{a}$ Distances are averages; standard deviations shown in parentheses.

compared to $0.1,0.1$, and $0.2 \AA$ in the iron, nickel, and zinc complexes, respectively; standard deviations of the metalmetal-metal angles (from the ideal $108^{\circ}$ of a pentagon) $2.2^{\circ}$ for the cobalt knot as compared to $0.7^{\circ}$ (iron), $1.5^{\circ}$ (nickel), and $1.7^{\circ}$ (zinc) pentafoil knots. The chloride anion is located at different distances from the plane of the metal ions in the different knot complexes, illustrating how the size, electrostatics, and shape of the knotted ligand cavity change with coordination to the different metal cations (Figure $2 \mathrm{~d}-\mathrm{f}$ ).

The packing of the zinc pentafoil knot $\left[\mathrm{Zn}_{5} \mathbf{1} \cdot \mathrm{Cl}\right]\left(\mathrm{BF}_{4}\right)_{9}$ differs from that of the other pentafoil knot coordination complexes. The crystal structure of $\left[\mathrm{Zn}_{5} \mathbf{1} \cdot \mathrm{Cl}\right]\left(\mathrm{BF}_{4}\right)_{9}$ features pairs of knots close-packed through $\pi$-stacking of phenyl rings of each ligand (shown in turquoise in Figure 3), with the knots separated by a layer of six tetrafluoroborate anions (shown in space-filling representation in Figure 3). Five of the anions are located between the metal centers, forming an array of $\mathrm{CH}_{1} \cdots \mathrm{F}$ bonds with the electron-poor $\mathrm{CH}_{1}$ atoms of the coordinated bipy ligands, with the sixth $\mathrm{BF}_{4}^{-}$anion directly between the two chloride anions. The sandwiched complexes stack in the unit cell, forming cationic pillars with anionic cores.

Chloride Binding Affinity of Metalated Pentafoil Knots. Isothermal titration calorimetry (ITC) was used to compare the chloride binding properties of the various metalated pentafoil knots (Table 4). Tetrabutylammonium chloride $\left(\mathrm{Bu}_{4} \mathrm{NCl}\right)$ was titrated into solutions of each chloride-

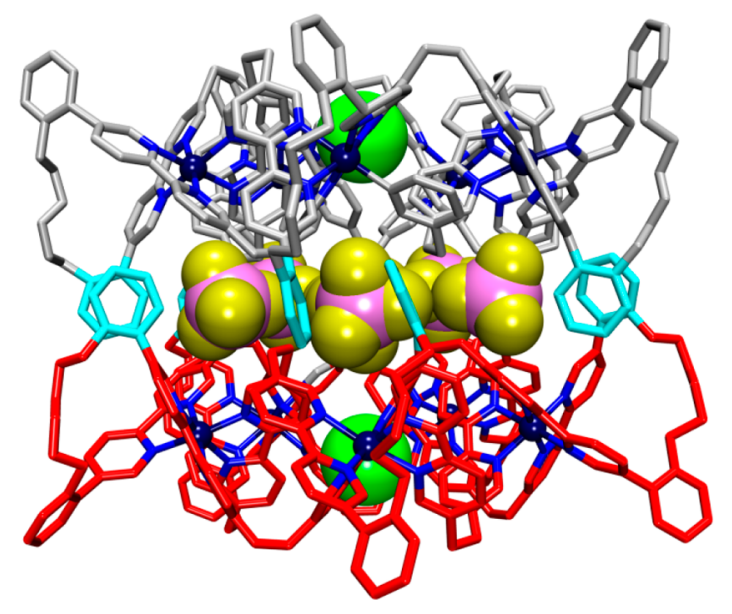

Figure 3. Packing of two $\left[\mathrm{Zn}_{5} \mathbf{1} \cdot \mathrm{Cl}\right]\left(\mathrm{BF}_{4}\right)_{9}$ complexes in the X-ray crystal structure, one shown with carbon atoms in gray, one with carbon atoms in red. Anions (chloride and tetrafluoroborate) depicted in space-filling representations. The phenyl rings shown in turquoise are involved in $\pi$-stacking between the two $\mathrm{Zn}_{5}$-pentafoil knots.

free knot, $\left[\mathrm{M}_{5} \mathbf{1}\right]\left(\mathrm{BF}_{4}\right)_{10}$, in dry acetonitrile. Each of the different metalated knots was found by ITC to strongly bind chloride ions (Figures S30 and 31). The knot:chloride stoichiometry in each case is $1: 1$, although the number of 
Table 4. Determination of $\mathrm{Cl}^{-}+\left[\mathrm{M}_{5} \mathbf{1}^{10+} \rightarrow\left[\mathrm{M}_{5} \mathbf{1} \cdot \mathrm{Cl}\right]^{9+}\right.$ Binding by Isothermal Titration Calorimetry in $\mathrm{MeCN}$

\begin{tabular}{lccccccc} 
& {$\left[\left[\mathrm{M}_{5} \mathbf{1}\right]\left(\mathrm{BF}_{4}\right)_{10}\right]\left(\mathrm{mol} \mathrm{L}^{-1}\right)$} & {$\left[\mathrm{NBu}_{4} \mathrm{Cl}\right]\left(\mathrm{mol} \mathrm{L}^{-1}\right)$} & $N(\mathrm{sites})$ & $K_{\mathrm{a}}\left(\mathrm{L} \mathrm{mol}^{-1}\right)$ & $\Delta G\left(\mathrm{~kJ} \mathrm{~mol}^{-1}\right)$ & $\Delta H\left(\mathrm{~kJ} \mathrm{~mol}^{-1}\right)$ & $-\mathrm{T} \Delta S\left(\mathrm{~kJ} \mathrm{~mol}{ }^{-1}\right)$ \\
{$\left[\mathrm{Fe}_{5} \mathbf{1}\right]\left(\mathrm{BF}_{4}\right)_{10}$} & $2.5 \times 10^{-5}$ & $2.0 \times 10^{-4}$ & 0.79 & $3.3(9) \times 10^{7}$ & -43.0 & $-33.0(5)$ & 10.1 \\
{$\left[\mathrm{Co}_{5} \mathbf{1}\right]\left(\mathrm{BF}_{4}\right)_{10}$} & $2.5 \times 10^{-5}$ & $2.0 \times 10^{-4}$ & 0.59 & $2.3(6) \times 10^{7}$ & -42.1 & $-25.6(4)$ & 16.5 \\
{$\left[\mathrm{Ni}_{5} \mathbf{1}\right]\left(\mathrm{BF}_{4}\right)_{10}$} & $1.0 \times 10^{-4}$ & $1.0 \times 10^{-3}$ & 0.86 & $3(3) \times 10^{7}$ & -42.9 & $-28.1(6)$ & 14.8 \\
{$\left[\mathrm{Cu}_{5} \mathbf{1}\right]\left(\mathrm{BF}_{4}\right)_{10}$} & $1.0 \times 10^{-4}$ & $1.0 \times 10^{-3}$ & 0.72 & $8(2) \times 10^{4}$ & -28.1 & $-22(2)$ & 5.8 \\
{$\left[\mathrm{Zn}_{5} \mathbf{1}\right]\left(\mathrm{BF}_{4}\right)_{10}$} & $2.5 \times 10^{-5}$ & $2.0 \times 10^{-4}$ & 0.75 & $5(1) \times 10^{6}$ & -38.4 & $-36.8(8)$ & 1.6 \\
\hline
\end{tabular}

chloride binding sites determined for each knot ( $N$ values, Table 4) was slightly lower than 1.0 , probably as a result of scavenging of traces of chloride ions from glassware/solvents by the "empty" knots prior to the ITC measurements. In all cases, the chloride binding was both enthalpically and entropically favorable. The chloride affinities were high and similar for the iron(II), cobalt(II), and nickel(II) pentafoil knots $\left(K_{\mathrm{a}}(2.3-3.3) \times 10^{7} \mathrm{M}^{-1}\right)$, an order of magnitude lower for the zinc(II) knot $\left(K_{\mathrm{a}} 5 \times 10^{6} \mathrm{M}^{-1}\right)$, and significantly lower for the copper(II) $k$ not $\left(K_{\mathrm{a}} 8 \times 10^{4} \mathrm{M}^{-1}\right)$.

The different $\mathrm{Cl}^{-}$affinities of the various metalated pentafoil knots presumably result from several factors, including (but not restricted to): how coordination to the different size and electronic geometries of the cations affects the conformation of the cavity, the strength of coordination bonds influencing the polarization of the $\mathrm{H}_{1}$ atoms, the strength of the long-range $\mathrm{M}$ (II) $\cdots \mathrm{Cl}^{-}$electrostatic attraction, and the tolerance of distortion of six-coordinate geometries by the different metal ions. In the absence of definitive structural data from X-ray crystallography, we cannot be sure as to the reasons why the $\mathrm{Cu}$ (II) pentafoil knot complex is a much more modest binder of chloride ions than the other metalated pentafoil knots. It may be that accommodating the size and shape of the five $\mathrm{Cu}$ (II) ions distorts the folded geometry of the pentafoil knotted ligand to such an extent that the cavity is no longer of appropriate size or shape (e.g., no longer directs all of the polarized $\mathrm{H}_{1}$ protons toward a single point in space) to bind $\mathrm{Cl}^{-}$.

\section{CONCLUSIONS}

A pentafoil knotted ligand 1, containing 15 bipyridine chelate residues in a 190-atom-long closed loop, forms "first-sphere" pentanuclear coordination complexes with a range of first row transition metal dications. The resulting complexes exhibit strong second-sphere coordination to a single chloride anion. $\mathrm{Zn}$ (II) ions, ${ }^{14}$ but not $\mathrm{Fe}(\mathrm{II}), \mathrm{Co}(\mathrm{II}), \mathrm{Ni}(\mathrm{II})$, or $\mathrm{Cu}(\mathrm{II})$, can be introduced directly into the knotted ligand, but the $\mathrm{Zn}$ (II) can be smoothly transmetalated with other metal(II) tetrafluoroborate salts to the pentanuclear $\mathrm{Fe}$ (II), $\mathrm{Co}$ (II), $\mathrm{Ni}$ (II), and $\mathrm{Cu}$ (II) knot complexes. The stepwise metal-ion-for-metal-ion substitution mechanism prevents the ligand from ever having sufficient vacant metal binding sites for incorrect binding modes to be adopted. The knotted ligands wrap around the five metal ions in a circular double helicate motif. Lehn-type circular helicates only form with tris-bipy strands and $\mathrm{Fe}(\mathrm{II})$ ions (and, in some cases, $\mathrm{Ni}(\mathrm{II})^{16}$ and $\mathrm{Zn}(\mathrm{II})^{10}$ ), and so this motif is only accessible with other metal(II) cations through such a knotted ligand. The X-ray crystal structures of the different pentanuclear knot complexes show conformational changes in the entangled ligand to accommodate the different sized metals. This results in a range of second-sphere coordination binding affinities for chloride ions that varies according to the metal ion over nearly 3 orders of magnitude, from $K_{\mathrm{a}}=8 \times 10^{4} \mathrm{M}^{-1}\left(\mathrm{Cu}_{5} 1\right)$ to $K_{\mathrm{a}}=3.3 \times 10^{7} \mathrm{M}^{-1}\left(\mathrm{Fe}_{5} 1\right)$ in acetonitrile. Knotting ligand strands imparts coordination chemistry that is inaccessible with constitutionally similar but unknotted ligands, a significant example $e^{4 a, 8-11}$ of the potential chemical consequences of molecular topology.

\section{ASSOCIATED CONTENT}

\section{S Supporting Information}

The Supporting Information is available free of charge on the ACS Publications website at DOI: 10.1021/jacs.8b12548.

Experimental section, synthetic overview, synthetic procedures and characterization details, NMR spectra, UV-vis spectra, ITC experiments, X-ray crystal structure information, and additional references (PDF)

X-ray crystallographic details for $\left.\left[\mathrm{Zn}_{5} \mathbf{1} \cdot \mathrm{Cl}\right]\left(\mathrm{BF}_{4}\right)_{9}\right]$ (CIF)

X-ray crystallographic details for $\left.\left[\mathrm{Co}_{5} \mathbf{1} \cdot \mathrm{Cl}\right]\left(\mathrm{BF}_{4}\right)_{9}\right]$ (CIF)

X-ray crystallographic details for $\left.\left[\mathrm{Ni}_{5} \mathbf{1} \cdot \mathrm{Cl}\right]\left(\mathrm{BF}_{4}\right)_{9}\right]$ (CIF)

\section{AUTHOR INFORMATION}

\section{Corresponding Author}

*david.leigh@manchester.ac.uk

ORCID ${ }^{\circ}$

Liang Zhang: 0000-0001-8605-8681

Christopher J. Robinson: 0000-0001-6146-566X

David A. Leigh: 0000-0002-1202-4507

\section{Notes}

The authors declare no competing financial interest.

\section{ACKNOWLEDGMENTS}

We thank the China 1000 Talents Plan, East China Normal University, the Engineering and Physical Sciences Research Council (EPSRC) (EP/P027067/1), the European Research Council (ERC) (Advanced Grant no. 339019), and the Biotechnology and Biological Sciences Research Council (BBSRC) (BB/M017702/1) for funding, the Diamond Light Source (UK) for Synchrotron beam time on I19 (XR029), and the University of Manchester for a President's Doctoral Scholar Award (to L.Z.). D.A.L. is a Royal Society Research Professor and a Thousand Talents Professor.

\section{REFERENCES}

(1) (a) Wasserman, S. A.; Cozzarelli, N. R. Biochemical topology: applications to DNA recombination and replication. Science 1986, 232, 951-960. (b) Vinograd, J.; Lebowitz, J. Physical and topological properties of circular DNA. J. Gen. Physiol. 1966, 49, 103-125. (c) Champoux, J. J. DNA topoisomerases: structure, function, and mechanism. Annu. Rev. Biochem. 2001, 70, 369-413.

(2) Lim, N. C. H.; Jackson, S. E. Molecular knots in biology and chemistry. J. Phys.: Condens. Matter 2015, 27, 354101. 
(3) Frank-Kamenetskii, M. D.; Lukashin, A. V.; Vologodskii, A. V. Statistical mechanics and topology of polymer chains. Nature 1975, 258, 398-402.

(4) (a) Fielden, S. D. P.; Leigh, D. A.; Woltering, S. L. Molecular knots. Angew. Chem., Int. Ed. 2017, 56, 11166-11194. For other reviews on molecular knots, see: (b) Fenlon, E. E. Open problems in chemical topology. Eur. J. Org. Chem. 2008, 2008, 5023-5035. (c) Beves, J. E.; Blight, B. A.; Campbell, C. J.; Leigh, D. A.; McBurney, R. T. Strategies and tactics for the metal-directed synthesis of rotaxanes, knots, catenanes, and higher order links. Angew. Chem., Int. Ed. 2011, 50, 9260-9327. (d) Forgan, R. S.; Sauvage, J.-P.; Stoddart, J. F. Chemical topology: complex molecular knots, links, and entanglements. Chem. Rev. 2011, 111, 5434-5464. (e) Amabilino, D. B.; Sauvage, J.-P. The beauty of knots at the molecular level. Top. Curr. Chem. 2011, 323, 107-126. (f) Ayme, J.-F.; Beves, J. E.; Campbell, C. J.; Leigh, D. A. Template synthesis of molecular knots. Chem. Soc. Rev. 2013, 42, 1700-1712. (g) Horner, K. E.; Miller, M. A.; Steed, J. W.; Sutcliffe, P. M. Knot theory in modern chemistry. Chem. Soc. Rev. 2016, 45, 6432-6448. (h) Sauvage, J.-P. From chemical topology to molecular machines (Nobel lecture). Angew. Chem., Int. Ed. 2017, 56, 11080-11093.

(5) (a) Dietrich-Buchecker, C. O.; Sauvage, J.-P. A synthetic molecular trefoil knot. Angew. Chem., Int. Ed. Engl. 1989, 28, 189192. (b) Ashton, P. R.; Matthews, O. A.; Menzer, S.; Raymo, F. M.; Spencer, N.; Stoddart, J. F.; Williams, D. J. A template-directed synthesis of a molecular trefoil knot. Liebigs Ann. Recueil 1997, 1997, 2485-2494. (c) Guo, J.; Mayers, P. C.; Breault, G. A.; Hunter, C. A. Synthesis of a molecular trefoil knot by folding and closing on an octahedral coordination template. Nat. Chem. 2010, 2, 218-222. (d) Barran, P. E.; Cole, H. L.; Goldup, S. M.; Leigh, D. A.; McGonigal, P. R.; Symes, M. D.; Wu, J. Y.; Zengerle, M. Active metal template synthesis of a molecular trefoil knot. Angew. Chem., Int. Ed. 2011, 50, 12280-12284. (e) Ayme, J.-F.; Beves, J. E.; Leigh, D. A.; McBurney, R. T.; Rissanen, K.; Schultz, D. A synthetic molecular pentafoil knot. Nat. Chem. 2012, 4, 15-20. (f) Ayme, J.-F.; Beves, J. E.; Leigh, D. A.; McBurney, R. T.; Rissanen, K.; Schultz, D. Pentameric circular iron(II) double helicates and a molecular pentafoil knot. J. Am. Chem. Soc. 2012, 134, 9488-9497. (g) Ayme, J.-F.; Gil-Ramírez, G.; Leigh, D. A.; Lemonnier, J.-F.; Markevicius, A.; Muryn, C. A.; Zhang, G. Lanthanide template synthesis of a molecular trefoil knot. J. Am. Chem. Soc. 2014, 136, 13142-13145. (h) Danon, J. J.; Krüger, A.; Leigh, D. A.; Lemonnier, J.-F.; Stephens, A. J.; VitoricaYrezabal, I. J.; Woltering, S. L. Braiding a molecular knot with eight crossings. Science 2017, 355, 159-162. (i) Zhang, L.; August, D. P.; Zhong, J.; Whitehead, G. F. S.; Vitorica-Yrezabal, I. J.; Leigh, D. A. A molecular trefoil knot from a trimeric circular helicate. J. Am. Chem. Soc. 2018, 140, 4982-4985. (j) Danon, J. J.; Leigh, D. A.; Pisano, S.; Valero, A.; Vitorica-Yrezabal, I. J. A six-crossing doubly interlocked [2]catenane with twisted rings, and a molecular granny knot. Angew. Chem., Int. Ed. 2018, 57, 13833-13837. (k) Zhang, L.; Stephens, A. J.; Nussbaumer, A. L.; Lemonnier, J.-F.; Jurček, P.; Vitorica-Yrezabal, I. J.; Leigh, D. A. Stereoselective synthesis of a composite knot with nine crossings. Nat. Chem. 2018, 10, 1083-1088.

(6) (a) Fujita, M.; Ibukuro, F.; Hagihara, H.; Ogura, K. Quantitative self-assembly of a [2]catenane from two preformed molecular rings. Nature 1994, 367, 720-723. (b) For selected examples of the synthesis of other interlocked molecular architectures featuring metal ion coordination, see: Leigh, D. A.; Lusby, P. J.; Teat, S. J.; Wilson, A. J.; Wong, J. K. Y. Benzylic imine catenates: Readily accessible octahedral analogues of the Sauvage catenates. Angew. Chem., Int. Ed. 2001, 40, 1538-1543. (c) Chichak, K. S.; Cantrill, S. J.; Pease, A. R.; Chiu, S.-H.; Cave, G. W. V.; Atwood, J. L.; Stoddart, J. F. Molecular Borromean rings. Science 2004, 304, 1308-1312. (d) Li, F.; Clegg, J. K.; Lindoy, L. F.; Macquart, R. B.; Meehan, G. V. Metallosupramolecular self-assembly of a universal 3-ravel. Nat. Commun. 2011, 2, 205. (e) Li, S.; Huang, J.; Cook, T. R.; Pollock, J. B.; Kim, H.; Chi, K.-W.; Stang, P. J. Formation of [3] catenanes from 10 precursors via multicomponent coordination-driven self-assembly of metallarectangles. J. Am. Chem. Soc. 2013, 135, 2084-2087. (f) Huang, S.-L.; Lin, Y.-J.; Hor, T. S. A.; Jin, G.-X. Cp* Rh-based heterometallic metallarectangles: size-dependent Borromean link structures and catalytic acyl transfer. J. Am. Chem. Soc. 2013, 135, 8125-8128. (g) Huang, S.-L.; Lin, Y.-J.; Li, Z.-H.; Jin, G.-X. Selfassembly of molecular Borromean rings from bimetallic coordination rectangles. Angew. Chem., Int. Ed. 2014, 53, 11218-11222. (h) Lincheneau, C.; Jean-Denis, B.; Gunnlaugsson, T. Self-assembly formation of mechanically interlocked [2]-and [3] catenanes using lanthanide ion $[\mathrm{Eu}(\mathrm{III})]$ templation and ring closing metathesis reactions. Chem. Commun. 2014, 50, 2857-2860. (i) Schouwey, C.; Holstein, J. J.; Scopelliti, R.; Zhurov, K. O.; Nagornov, K. O.; Tsybin, Y. O.; Smart, O. S.; Bricogne, G.; Severin, K. Angew. Chem., Int. Ed. 2014, 53, 11261-11265. (j) Wood, C. S.; Ronson, T. K.; Belenguer, A. M.; Holstein, J. J.; Nitschke, J. R. Two-stage directed self-assembly of a cyclic [3] catenane. Nat. Chem. 2015, 7, 354-358. (k) ThorpGreenwood, F. L.; Kulak, A. N.; Hardie, M. J. An infinite chainmail of $\mathrm{M}_{6} \mathrm{~L}_{6}$ metallacycles featuring multiple Borromean links. Nat. Chem. 2015, 7, 526-531. (1) Zhu, R.; Lübben, J.; Dittrich, B.; Clever, G. H. Stepwise halide-triggered double and triple catenation of selfassembled coordination cages. Angew. Chem., Int. Ed. 2015, 54, 2796-2800. (m) Beves, J. E.; Danon, J. J.; Leigh, D. A.; Lemonnier, J.-F.; Vitorica-Yrezabal, I. J. A Solomon link through an interwoven molecular grid. Angew. Chem., Int. Ed. 2015, 54, 7555-7559. (n) Galli, M.; Lewis, J. E. M.; Goldup, S. M. A stimuli responsive rotaxane-Au catalyst: Regulation of activity and diastereoselectivity. Angew. Chem., Int. Ed. 2015, 54, 13545-13549. (o) Denis, M.; Pancholi, J.; Jobe, K.; Watkinson, M.; Goldup, S. M. Chelating rotaxane ligands as fluorescent metal ion sensors. Angew. Chem., Int. Ed. 2018, 57, 5310-5314.

(7) (a) Safarowsky, O.; Nieger, M.; Fröhlich, R.; Vögtle, F. A molecular knot with twelve amide groups-one-step synthesis, crystal structure, chirality. Angew. Chem., Int. Ed. 2000, 39, 1616-1618. (b) Feigel, M.; Ladberg, R.; Engels, S.; Herbst-Irmer, R.; Fröhlich, R. A trefoil knot made of amino acids and steroids. Angew. Chem., Int. Ed. 2006, 45, 5698-5702. (c) Ponnuswamy, N.; Cougnon, F. B. L.; Clough, J. M.; Pantos, G. D.; Sanders, J. K. M. Discovery of an organic trefoil knot. Science 2012, 338, 783-785. (d) Prakasam, T.; Lusi, M.; Elhabiri, M.; Platas-Iglesias, C.; Olsen, J.-C.; Asfari, Z.; CianféraniSanglier, S.; Debaene, F.; Charbonnière, L. J.; Trabolsi, A. Simultaneous self-assembly of a [2]catenane, a trefoil knot, and a Solomon link from a simple pair of ligands. Angew. Chem., Int. Ed. 2013, 52, 9956-9960. (e) Ponnuswamy, N.; Cougnon, F. B. L.; Pantos, G. D.; Sanders, J. K. M. Homochiral and meso figure eight knots and a Solomon link. J. Am. Chem. Soc. 2014, 136, 8243-8251. (f) Kim, D. H.; Singh, N.; Oh, J.; Kim, E.-H.; Jung, J.; Kim, H.; Chi, K.-W. Coordination-driven self-assembly of a molecular knot comprising sixteen crossings. Angew. Chem., Int. Ed. 2018, 57, 5669-5673. (g) Leigh, D. A.; Lemonnier, J.-F.; Woltering, S. L. Comment on "Coordination-driven self-assembly of a molecular knot comprising sixteen crossings. Angew. Chem., Int. Ed. 2018, 57, 1221212214. (h) Cougnon, F. B. L.; Caprice, K.; Pupier, M.; Bauza, A.; Frontera, A. A strategy to synthesize molecular knots and links using the hydrophobic effect. J. Am. Chem. Soc. 2018, 140, 12442-12450.

(8) (a) Ayme, J.-F.; Beves, J. E.; Campbell, C. J.; Gil-Ramírez, G.; Leigh, D. A.; Stephens, A. J. Strong and selective anion binding within the central cavity of molecular knots and links. J. Am. Chem. Soc. 2015, 137, 9812-9815. (b) Bilbeisi, R. A.; Prakasam, T.; Lusi, M.; ElKhoury, R.; Platas-Iglesias, C.; Charbonnière, L. J.; Olsen, J.-C.;

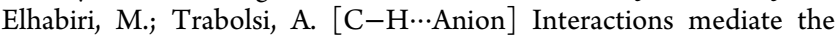
templation and anion binding properties of topologically non-trivial metal-organic structures in aqueous solutions. Chem. Sci. 2016, 7, $2524-2532$.

(9) Gil-Ramírez, G.; Hoekman, S.; Kitching, M. O.; Leigh, D. A.; Vitorica-Yrezabal, I.; Zhang, G. Tying a molecular overhand knot of single handedness and asymmetric catalysis with the corresponding pseudo- $\mathrm{D}_{3}$-symmetric trefoil knot. J. Am. Chem. Soc. 2016, 138, 13159-13162.

(10) Marcos, V.; Stephens, A. J.; Jaramillo-Garcia, J.; Nussbaumer, A. L.; Woltering, S. L.; Valero, A.; Lemonnier, J.-F.; Vitorica-Yrezabal, 
I. J.; Leigh, D. A. Allosteric initiation and regulation of catalysis with a molecular knot. Science 2016, 352, 1555-1559.

(11) Leigh, D. A.; Pirvu, L.; Schaufelberger, F.; Tetlow, D. J.; Zhang, L. Securing a supramolecular architecture by tying a stopper knot. Angew. Chem., Int. Ed. 2018, 57, 10484-10488.

(12) (a) Dietrich-Buchecker, C. O.; Sauvage, J.-P.; Armaroli, N.; Ceroni, P.; Balzani, V. Knotted heterodinuclear complexes. Angew. Chem., Int. Ed. Engl. 1996, 35, 1119-1121. (b) Dietrich-Buchecker, C. O.; Hwang, N. G.; Sauvage, J.-P. A trefoil knot coordinated to two lithium ions: synthesis and structure. New J. Chem. 1999, 23, 911914. (c) Prakasam, T.; Bilbeisi, R. A.; Lusi, M.; Olsen, J.-C.; PlatasIglesias, C.; Trabolsi, A. Postsynthetic modification of cadmium-based knots and links. Chem. Commun. 2016, 52, 7398-7401.

(13) Miyake, H.; Tsukube, H. Coordination chemistry strategies for dynamic helicates: time-programmable chirality switching with labile and inert metal helicates. Chem. Soc. Rev. 2012, 41, 6977-6991.

(14) In response to a reviewer's suggestion, preliminary results show that direct metalation of the pentafoil knotted ligand 1 with $\mathrm{MnCl}_{2}$ for 2 days at room temperature, followed by anion exchange, successfully generates the corresponding $\left[\mathrm{Mn}_{5} \mathbf{1} \cdot \mathrm{Cl}\right]\left(\mathrm{BF}_{4}\right)_{9}$ complex. This is consistent with the relatively fast coordination dynamics of typical $\mathrm{Mn}$ (II) complexes (first-sphere coordination water exchange is faster for $\mathrm{Mn}(\mathrm{II})$ than $\mathrm{Fe}(\mathrm{II})$, for example, although slower than $\mathrm{Zn}(\mathrm{II})$ ). Similarly, direct metalation of 1 with $\mathrm{Cd}(\mathrm{OAc})_{2}$, another metal salt with fast ligand exchange dynamics, resulted in the formation of $\left[\mathrm{Cd}_{5} \mathbf{1}\right](\mathrm{OAc})_{10}$. These preliminary results will be reported fully in due course.

(15) Carnes, M. E.; Collins, M. S.; Johnson, D. W. Transmetalation of self-assembled, supramolecular complexes. Chem. Soc. Rev. 2014, $43,1825-1834$.

(16) (a) Hasenknopf, B.; Lehn, J.-M.; Kneisel, B. O.; Baum, G.; Fenske, D. Self-assembly of a circular double helicate. Angew. Chem., Int. Ed. Engl. 1996, 35, 1838-1840. (b) Hasenknopf, B.; Lehn, J.-M.; Boumediene, N.; Dupont-Gervais, A.; Van Dorsselaer, A.; Kneisel, B.; Fenske, D. Self-assembly of tetra- and hexanuclear circular helicates. J. Am. Chem. Soc. 1997, 119, 10956-10962. (c) Hasenknopf, B.; Lehn, J.-M.; Boumediene, N.; Leize, E.; Van Dorsselaer, A. Kinetic and thermodynamic control in self-assembly: sequential formation of linear and circular helicates. Angew. Chem., Int. Ed. 1998, 37, 32653268. 